\title{
Suya İşlenen Edebiyat: Kanunî Sultan Süleyman'ın Su Vakfiyesi Örneği
}

\section{Water in Turkish Literature: The Example of Sultan Suleiman's Water Foundation}

\section{Gülșen Sezen ${ }^{1}$ [D}

'Dr., Bağımsız Araştırmacı, İstanbul, Türkiye

ORCID: G.S. 0000-0003-2924-5944

Sorumlu yazar/Corresponding author:

Gülşen Sezen

Bağımsız Araştırmacı, İstanbul, Türkiye

E-mail: sezen_g@windowslive.com

Başvuru/Submitted: 29.07.2020

Revizyon Talebi/Revision Requested:

18.11.2020

Son Revizyon/Last Revision Received:

24.11.2020

Kabul/Accepted: 03.12 .2020

\section{Atıf/Citation:}

Sezen, G. (2020). Suya işlenen edebiyat: Kanunî Sultan Süleyman'ın su vakfiyesi örneği. TUDED 60(2), 719-734

https://doi.org/10.26650/TUDED2020-0049

\section{ÖZET}

Hayırlı bir iş için sahip olunan malı veya geliri tahsis etmekle oluşturulan vakıfların geçmişi İslamiyet'in ilk yıllarına kadar dayandırılmaktadır. Vakıf kurmak ve onu işletmek İslamiyet'in yoğun etkisiyle bir kültür olarak Osmanlı topraklarında da sürdürülmüş ve vakıfların daima özel bir yeri olmuştur. Bilindiği kadarıyla Osmanlı Devleti'nde su için vakıf kuran ilk kişi Kanunî Sultan Süleyman'dır. 16. yüzyılda (24-31Aralık 1565) tesis edildiği bilinen bu vakfa ait metin (vakfiye", senet, vakıfnâme) çalışmamızın konusu olarak belirlenmiştir. Vakfiyede geçen suya dair ibareler, anlatımlar, tasvir ve betimlemeler, övgüler, benzetmeler, vb. yaşatılan kültürün toplum hafızasına nasıl yerleştiğinin ve ne yönde geliştiğinin delili olarak görülebilir. Bu manada edebiyatın suya işlenen yönünü gösteren su vakfiyesinden yola çıkarak suyun hem dildeki yansımasını hem de kültürdeki karşılıklarını tespit etmek makalenin temel amacıdır. Amaç dâhilinde okyanus, deniz, ırmak, pınar, yağmur, nisan yağmuru, memba, saf su, damla, cennet suları, Kâğıthane Suyu, hayat suyu (abıhayât) gibi su öğelerinin yanı sıra; su kemeri, köprü, hamamlar, su ayă̆ı, sebil, çeşme, havuz gibi su mimarîsine ait eserler ele alınmıştır.

Anahtar Kelimeler: Su, kültür, vakıf/vakfiye, Kanunî Sultan Süleyman, İstanbul

\section{ABSTRACT}

The charitable allocation of a property or income to a foundation in the form of a trust dates to the first years of Islam. This foundation tradition influenced Islamic regimes intensely and continued in the Ottoman Empire, where it always retained a special place. In the $16^{\text {th }}$ century (December $24-31,1565$ ), Sultan Suleiman established a foundation for water in the Ottoman Empire that was named after him. The charter for this organization, called a vakfiye or vakifnâme, is the main subject in this study. Words, expressions, descriptions and imagery, compliments, metaphors, etc., all of which pertain to water, are present in the vakfiye text. These can be taken as evidence of how water culture emerged and lived in social memory and of the direction in which it developed. The main purpose of this article is to describe how water imagery reflects both language and culture. Accordingly, numerous references to water in the subject matter of the study are examined, for example: ocean, sea, river, fountain, rain, April rain, spring water, pure water, rain drop, heavenly waters, River of Kagithane, water of life etc. Some relevant architectural terms are also considered; water arch, bridge, bath, haunch, public fountain, fountain, and pool.

Keywords: Water, culture, foundation/trust, Sultan Suleiman, Istanbul

*Vakfiye: "Vakfedilen bir malın hangi hayır işine tahsis edileceğini, ne şekilde ve hangi şartlarla yönetileceğini gösteren mahkemece onaylanmıs senet, vakıfnâme" demektir ve "vakfa ait, vakıfla ilgili" manasına gelecek şekilde kullanılır. Bkz. (Kubbealtı Lugati) 


\section{EXTENDED ABSTRACT}

Water, which came to signify wealth, prosperity, fortune, and credit to the state, raised the Ottoman Empire to the level civilization. Sultan Suleiman established a foundation for water in the Ottoman Empire that was named after him. All income earned from certain villages, townships, fields, territories, and regions was allocated to support the work of the water foundation by Sultan Suleiman. ${ }^{1}$ Procedures and responsibility for the work of the water foundation were set out in a foundation document called a vakifnâme or vakfiye. According to the document, a decision was made to give overall incomes to the foundation for repair of water supply systems, fountains, buildings, ways, arches, etc. which were under the foundation's charge. It was stipulated that the funds from certain mosques, madrasahs, holy temples, and hospices in Istanbul, would be transferred to the foundation if its income was not enough for repair. All properties and possessions of the foundation were transferred to vizier/sadr-i azam Mehmed Pasha, son of Sinan, as trustee. He was given the responsibility for such tasks as setting up the foundation, recording procedures, registration, and making instructions. Gulabi Agha, son of Abdulhalim, and Numan, son of Abu Khanifa Sabit, were also chosen as trustees. In the event the foundation had a problem, Imam Abu Yusuf and Imam Muhammed Sheibani were charged with giving judicial decision according to Islamic laws. A curse was set on anyone who made a change or who ignored the jurisdiction of the foundation; it was said may the sin of this (and the curse of Allah, angels and all people) be upon them. The date of the foundation's establishment was determined as December 24-31, 1565 (AD), the $973^{\text {rd }}$ year of Hegira.

The aforementioned foundation documentis the subject matter of this study, whose main purpose is to trace water culture through close reading of the document. Accordingly, the text was first translated into modern Turkish, after which it was scrutinized, and certain deductions made. Islamic elements were frequently included in the charter, encompassing which properties of water were acceptable, ${ }^{2}$ the supposed healing properties of water, etc. Therefore, for example, water is cause to express one's thanks, evidence of God's creative power and wisdom, and an example of unlimited justice and truthfulness. It represents the authority that the Sultan must have; it is a reason to seek achievement/goodness/kindness and is a good deed of Sultan. Finally, it is a metaphor to express Islamic conditions and the truths of theological-earthly-definite knowledge, whether as a symbol of the breadth of sovereignty or as a metaphor for God's mercy sought through prayer and good wishes. It is a nurturing force that causes growth. It provides frequent opportunity to remember the Sultan in a good way, and to describe the favors he has accomplished. It is a sign of the long-term and of the continuity of time, and is used to wish people well. It is a sign of the Sultan's benevolence to give it to his own nation., It is used a metaphor for a place to inspirations come. It justified the production of innumerable structures, raises cities to the level of civilizations, and gives to them

1 These villages, towns, fields, ... etc. can be identified: (Ateş, 1987, s. 14-6, 28-30)

2 Always flowing, enough of everyone, clean and pure, rare and precious, delicate, in good health, curative, swallowing easily. (Ateş, 1987, s. 27, 31) 
a rare beauty. It is an indispensable item of heavenly imagery, and of one's place in heaven, giving everyone the opportunity to reach heaven. It is a symbol of blessing and proof of plenty, and essential element of life. It make a view/building fascinating. It provides thanks to God in prays. It is a symbol for theological knowledge and a resemblance of one's nature glorified. 


\section{GİRiş}

Bir ülke için varlık, devlet ve itibar demek olan su, Osmanlı Devleti’ni medeniyet seviyesine yükselten unsurlardan olmuştur. Üstelik Anadolu coğrafyası, özellikleri yönünden tam bir su havzası olarak bilinir. İslamiyet'te özel bir yeri olan suya hürmet etmek dini vecibe gibi algılanmıştır. ${ }^{3}$ Sözgelimi çeşme kitabelerinde suya dair ayet ve hadislere yer vermek Anadolu'da bir gelenek hâlini almıştır. İmkânı ölçüsünde herkes başta kutsal topraklara giden kaynaklar olmak üzere suyun yolunu, yönünü güzelleştiren bir eylemde bulunmaya çalışmıştır. Hayır için ücretsiz şekilde; zülal suyu, şerbet ve doğal kaynak suyu dağıtan sebiller, yolcuların ihtiyaçlarını karşılamak için sefer yollarına inşa edilmiştir. Kuşlar susuz kalmasın diye mezar taşlarının üstüne yağmur suyunun toplanacağı küçük oyuklar yapılmıştır. Arklar ve kanallar sayesinde yerleşim merkezlerine taşınan su, maksimlerde şebekelere bölünüp su terazileri aracılığıyla basıncı dengelendikten sonra; evlere, hanlara, ibadet mekânlarına bağlanmıştır. Su temelli otomatların yapımıyla mekanik biliminde ilerleme kaydedilmiş (Sezen, 2020, s. 10-1, 1078), hidrolik mimarî yapılar Osmanlı topraklarında yükselmiştir.

Su yapısı inşa etme konusunda ufak da olsa katkıda bulunma âdeti halk arasında 1srarla sürdürülmüştür. Çünkü su, halk inancında kutsal bir varlıktır ve yaşamın kaynağıdır. ${ }^{4}$ Suyun taşınması ve kullanılması için oluşturulan su mimarîsi Osmanlı topraklarında birer birer yükselirken halkın dilinde suya dair deyimlerin, atasözlerinin ve duaların belirmeye başlaması ise onun kültür olarak dile işleyen yönünü teşkil etmiştir. Suyun bu dil yönünü İbrahim Ateş şöyle dile getirmiştir:

“Atalarımızın takdir edip beğendikleri, iyi dilek ve duada bulunmak istedikleri kimselere 'su gibi aziz ol' sözleri, suya verdikleri değerin ifadesidir. Diğer taraftan kendilerine bir bardak su ikram eden kimseye 'su gibi devlet bul' sözleri suyun varlık, devlet ve itibar vesilesi olduğu yolundaki düşünce ve inançlarını ifade etmektedir. (...) Müslüman Araplar, herhangi bir şeyin bolluğunu ifade ederken 'erhas min turâb' yani 'topraktan daha ucuz' deyimini kullanırlarken, yurdumuzda bir şeyin bolluk ve ucuzluğunu dile getirirken 'sudan ucuz' dememiz, böylesine değerli bir nimetin ülkemizdeki zenginliğini belirtmektedir.” (Ateş, 1987, s. 1-2)

Başlı başına bir kültüre dönüşme yoluna girdiği görülen su; türlü inanç, gelenek ve adetlerin özünde bulunması hasebiyle de yaşanan kültürün zenginliğini artırmıştır. ${ }^{5}$ Bu manada; mimarî ile kültürün odak noktası su olduğunda karşılaşılan devlet temelli hizmetlerin bir tanesinin

3 “İslâmiyet'te en büyük sevapların başında, susuzlara içme suyu temîni gelir; birçok âyet ve hadiste de suyun önemi vurgulanır. İstanbul' da pâdişahlar ve yakın çevresindekiler başta olmak üzere maddî gücü yeten herkes, su temîni için gerekli çeşme ve sebil gibi hayrat yapıları yaptırmaya çalışmış ve bunların onarımlarını, bakımlarını üstlenmiştir.” (Sarıdikmen, 2017/2, s. 201)

4 Suyun eski Türk inançlarındaki kutsallığına ve günümüzdeki yansımalarına dair bkz. (Karakurt, 2011); (Ögel, 2014); (Kolektif, 5-8 Mayıs 2000); (Acar, 2013); (Kuruçay, 2017/2).

5 Şifa tasları, âbıhayât, şifalı su inanışları, nisan yağmuruna dair inanışlar, su falı, hıdrellez gelenekleri gibi suyun kültürel yansımaları hakkında ayrıntılı bilgi için bkz. (Sezen, 2020, s. 8-22, 91-168); (Acar, 2013); (Kuruçay, 2017/2). 
vakıflar olduğu görülür. ${ }^{6}$ Bilindiği kadarıyla Osmanlı Devleti zamanında su için vakıf kuran ilk isim Kanunî Sultan Süleyman'dır ${ }^{7}$ ve vakfın işlemesi için beş köy ile bir kasabanın gelirinin vakfa hibe edilmesini, şayet bu da yeterli gelmezse Süleymaniye külliyesinin gelirinden vakfa aktarılmasını şart koşmuştur (Ateş, 1987, s. 5). Böylece tadilat ve tamiratlarına yetecek kadar bütçeye sahip olan vakfın ömrü uzatılmış, uzun yıllar boyunca işler halde ayakta kalması sağlanmıştır. ${ }^{8}$

\section{Su Vakfiyesi’nde Yaşatılan Su Kültürü}

Kanunî Sultan Süleyman'ın kurduğu su vakfı için bir metin (vakıfnâme, vakfiye) yazılmıştır.' Makaleye konu edilen bu metindeki su öğelerine bakıldığında su kültürünün yaşayan izlerine, bir toplumun hayal dünyasına ve kabullerine dair pek çok bilgi toplanabilmektedir. Makalenin buradan sonraki kısmında vakfiyedeki suya dair kültür öğeleri merkeze alınarak suyun yansımaları gösterilmeye çalışılacaktır. Bunun için önce metin ve metnin günümüz Türkçesine çevirisi tırnak içinle verilecek, ardından su öğelerinden yola çıkılarak açıklamalar yapılacaktır. ${ }^{10}$

"Ebhâr-1 azîme gibi bî-hadd ü bî-gâye ve enhâr-1 amîme-veş bî-kıyâs u bî-nihâye, hamdhâ-yı besyâr ve şükrhâ-yı bî-şumâr,” (Ateş, 1987, s. 9)

“Büyük denizler gibi sınırsız ve sonsuz, yaygın ırmaklar gibi ölçüsüz ve nihayetsiz pek çok hamd ü senâlarla sayısız şükürler; [...] büyüklük ve kerem sahibi olan Melik" (Ateş, 1987, s. 20)

İlk olarak Allah'ın övgüsüyle başlayan vakfiyenin satırlarında Allah'a edilen hamd ü senanın (verilen nimetlere şükrederek övmek) sınırsızlığını anlatmak için deniz ve ırmak benzetmesi yapıldığı görülmektedir. Deniz, sınırsızlık ve sonsuzluğun simgesi halinde tasvir

6 Su vakıfları yalnızca padişahlar tarafından değil saray mensupları (hanım sultanlar), vezirler, şeyhülislâmlar yahut siviller tarafindan da inşa edilmiştir. Bkz. (Öztürk, 2017/2, s. 129).

7 Sultan Süleyman'ın kurduğu vakıflara ait vakfiyeler şunlardır: 1) Süleymaniye külliyesi vakfiyesi 2) Su vakfiyesi 3) Hz. İbrahim zaviyesi vakfiyesi 4) Şam hayrat-1 şerife vakfiyesi. Bkz. (Ateş, 1987, s. 5-7). Padişahın su inşalarına verdiği önem seyyah Werner'in de dikkatini çekmiştir: “...Sultan Süleyman'ın gerçekleştirmesini umduğu en önemli arzularını da burada belirteyim: Sultan, ölmeden önce Tanrı'dan üç arzusunu gerçekleştirebilmesini nasip etmesini dilemiş: Birincisi, Aqua ductum adı verilen ve Konstantinopolis'e içme suyunu getiren su kemerlerini yenilemek ve inşa etmek, ikincisi oldukça geniş olan bu deniz uzantılarının üzerinden aşan köprüleri onarmak, üçüncüsü de Avusturya'ya sefer düzenleyip Viyana'yı almak... Sultan her iki dileğini gerçekleştirmeyi başarmıştır: Çok özel becerilerin ve şaşılacak yeniliklerin uygulanmasıyla, kente yetecek kadar tatlı suyun 5 mil uzunluğundaki yoldan, kurşun borulardan geçirtilerek Konstantinopolis'e getirilmesi başarılmış ve bu su 2000 çeşmeye dağıtılmıştır. Sultan, bununla da gerçekten bir hükümdara yakışır önemli bir işi başarmıştır. Ayrıca Daha önce birkaç kez sözünü ettiğim diğer köprüleri de büyük harcamalarla yenilenmiştir. Ama üçüncü dileğinin yerine gelmesini, düzenlediği iki büyük sefere rağmen, Tanrı nasip etmemiştir.” Bkz. (Werner, 2011, s. 54)

8 Vakfin kurulup tescil edilme tarihi hicretin 973. yılı (24-31 Aralık 1565) olarak gösterilmiştir Bkz. (Ateş, 1987, s. 33) Vakıf sayesinde Kâğıthane suları İstanbul'un iç beldelerine kadar getirilmiştir. Bkz. (Ateş, 1987, s. 5)

9 Vakıflar genel müdürlüğü arşivinde özel kasada muhafaza edildiği aktarılan, kasa no.67, genel no.1388'de [1338?] kayıtlı orijinal vakfiye defteri “evail-i Cemaziye'l-âhir 973 H. (24-31 Aralık 1565 M.)” şeklinde tarihlendirilmiştir. Vakfiye 29 varaktır. Bkz. (Ateş, 1987, s. 6-7). Metnin müellifi tespit edilememiştir.

$10 \mathrm{Bu}$ inceleme sırasında metindeki su öğeleri tarama yöntemiyle tespit edilmiştir. Anlamın bozulmamasına gayret edilerek öğenin metinde geçtiği dize alıntılanmıştır. 
edilirken ırmaklar ise kıyas edilemezlik ve nihayetsizlik karşılığında kullanılmıştır. Dolayısıyla toplum zihninde en temel seviyede; büyüklük, enginlik, sınırsızlık karşılığı olarak deniz ve 1rmak imgelerinin belirdiği anlaşılmaktadır.

“matâli'-i envâr ve mevâkı'-1 emtâr olan tâkât-1 ulviyyeyi muhît-i hadrâda tenvîr ve mazâhir-i sun' u esrâr ve mecârî-i uyûn ve enhâr olan tabakât-1 sufliyyeyi basît-i gabrâda tasvîr eyleyüp kudret-i kâmile ve hikmet-i şâmilesine delîl-i zâhir eyledi.” (Ateş, 1987, s. 9)

"Nurların doğduğu ve yağmurların yağdığı yerler olan yüce kubbeleri [tâkât-1 ulviyye] gökyüzünde aydınlatıp; yapıp var etme kudretiyle sırların göründüğü, pınar ve 1rmakların aktığg yerler olan alt katları ${ }^{11}$ [tabakât-1 sufliyye] yeryüzünde şekillendirip eksiksiz kudretine ve kapsamlı hikmetine açık delil kılmıştır.” (Ateş, 1987, s. 20)

Allah'ın yaratma, yoktan var etme gücünün ve hikmetinin delili olarak dizelerde; "yağmur yağdırmak, yağmurun doğduğu mekân olan gök kubbeyi aydınlatmak, pınar ve ırmakların aktığı yeryüzü katmanlarını şekillendirmek" örnekleri verilmiştir. Gök ile yer arasında husule gelen irtibatta "bereket” çağrışımı yapan su unsurlarına yer verildiği görülmektedir.

“âl-i Osmânı husûsâ adl u dâdun ummânı ve lutf u mürüvvet kânı [...] idüp" (Ateş, 1987, s. 9)

“[Allah,] Osmanoğulları Sultanları[nı], özellikle adalet ve doğruluğun ummanı [okyanusu], iyilik ve cömertlik kaynağı[madeni kılmıştır.]” (Ateş, 1987, s. 21)

Klasik Türk şiirinde kalıplaşmış kullanımlardan biri “adaleti, cömertliği” okyanus ve maden ile bağdaştırmaktır. Çokluk, sınırsızlık, kuşatıcı olmak, süreklilik çağrıştırmak, yok edici olmak gibi yönleriyle okyanus burada adalet ve doğrulukla ilişkilendirilmiştir. Cümlenin devamında ise iyilik ve cömertlik madene benzetilmiştir. Okyanus ile maden, Osmanlı padişahlarının taşıması gereken özelliklerin haddini anlatmak için kullanılmıştır.

“sultân-1 selâtîn Süleymân-1 zamân [...] cevâmi'-i seniyye ve inşâ-1 kanâtır ve savâmi'-i behiyye ve icrâ-i uyûn ve tecdîd-i tâkât-1 celiyye bâbında sa'y-1 cemîllerin cezîl ve vâfir eyledi” (Ateş, 1987, s. 9-10)

“[...] zamanın Süleyman'1 [...] güzel köprülerle ibadet yerleri inşa etmek, pınarları akıtmak ve mevcut kemerleri yenilemek hususunda güzel gayretlerini çok ve bolca eylemiştir.” (Ateş, 1987, s. 21)

11 Tasavvufa göre dünyanın yaratılışında rolü olan kuvvetler iki türlüdür: 1) Abâ-i ulviyye/Tâkât-1 ulviyye: Yücede/ yüksekte/gökte bulunan babalar, diğer bir deyişle dokuz felek. 2) Ümmehât-1 sufliyye/Tabakât-1 sufliyye: Feleklerin aşağısında (dünyada) bulunan anneler yani dört temel element olan; hava, su, ateş, toprak. -Mevâlid-i selâse (üç çocuk): Dokuz felek (baba) ile dört elementin (anne) birleşmesiyle meydana gelen; hayvanlar, bitkiler, madenler/ cansızlar. Konu hakkında bilgi için bkz. (Cebecioğlu, ty., s. 203-4, 209-10). Metinde geçen "yüce kubbeler" ile "alt katlar" deyişi yaratılışta temel rol üstlenen baba ve anne güçleri temsil eder. Bir başka deyişle Allah'ın yaratma kuvveti üreme davranışı üzerinden misalle verilmektedir. Yaratılışın üreme davranışı ile alakalandırılması konusunda bkz. (Yaratılış, s. 1:1-31, 2:1-3, 4:1); (Batuk, 2006/2, s. 51-96); (Sezen, 2020, s. 41-3). 
Metinde Kanunî Sultan Süleyman'ın meziyetleri, başarıları sıralanırken yaptırdığı su inşalarının bahsi geçer. Bunlar arasında; güzel köprüler yapmak, pınarları akıtıp su kemerleri aracılığı ile gerekli yerlere ulaştırmak ve bu yapıları yer yer tamir edip yenilemek vardır. Padişahın böylesi davranışları güzel gayretler arasında sayılmaktadır. ${ }^{12}$ Onun gayretlerinin sürekliliği vurgulanırken bunun bir kereliğine mahsus olmadığı söylenmiştir. Dolayısıyla Sultan'ın gayretinin güzelliği daima tazelenmektedir.

“bahr-i hakâyık-1 ilm-i ledünnî ve nehr-i dekâyık-1 lımmî ve innî, menba'-1 hıyâz-1 şerî'at" (Ateş, 1987, s. 10)

“[...] ilm-i ledünnî gerçeklerinin denizi, aklî ve kat‘î gerçeklerin nehri, şeriat havuzlarının menba'1, [...]” (Ateş, 1987, s. 21)

Hz. Muhammed övgüsünde dile getirilen dizelerde geçen ledünnî ilimden kasıt, Allah bilgisine ve sırlarına ait ilimdir. Peygamber gerek miraç sırasında Allah'a olan yakınlığı dolayısıyla gerekse de kendisine bahşedilen resullük dolayısıyla ledünnî ilimlerden yana irfan sahibi addedilir. İlmin denize benzetilmesi literatürde oldukça yaygın bir kullanımdır. Nitekim kamus (sözlük, lügat) kelimesinin kökence "okyanus" sözcüğüne dayandırılması "su ile ilim" benzeştirmesinin dilde köklü şekilde yer edindiğini gösterir. ${ }^{13}$ Deniz ile ilim; hadsizlik, enginlik, derinlik, içinde akıl sır almaz güzellikler ve nimetler bulundurmak, daima kendini yenilemek, üretmek gibi yönlerden benzeştirilir. Dizelerde hakikat/gerçeklik önce denize sonra nehre benzetilmiştir. Denize benzetilen hakikat ledünnî iken nehre benzetilen hakikat aklî ve kat 'îdir. Şeriat ise havuz ile benzeştirilmiştir. Havuzun durağanlığında şeriatın değişmez kanunlarını ararken hakikatin akışkanlığında ledünnîliği, aklîliği ve kat‘iliği aramak mümkündür.

“melikü’l-berreyn ve'l-bahreyn” (Ateş, 1987, s. 11)

“İki kara ve iki denizin sultanı [olan Kanunî Sultan Süleyman]” (Ateş, 1987, s. 23)

İfadede bahsi geçen "iki kara" Rumeli ile Anadolu'dur, "iki deniz" ise Akdeniz ile Karadeniz'dir. "Kara ve denizlerin sultanı olmak” ifadesi, kullanımına yaygın şekilde rastlanan bir unvandır. Egemenliği ve hükümranlığı belirten bu ifade, geçtiği metindeki bağlama göre bir padişah için kullanılabilecek en üst seviyedeki unvanlardandır. Böylelikle yalnızca ülke sınırlarının bulunduğu kara-toprak hâkimliğiyle kalınmayıp denizlerin egemenliği de

12 “[...] Müslüman-Türklerin birçok yönde olduğu gibi bu alanda da gösterdikleri gayret ve ortaya koydukları tesisler, her türlü takdirin üstündedir. Bu tesisler, başta insanlar olmak üzere birçok canlı varliğın faydalanacağı bend, havuz, gölet, kuyu, çeşme, sebil, şadırvan, hamam ve benzeri yapllarla bunlara su getiren su yolları, kanal ve kemerlerdir. Su vermenin sadakanın en üstünü olduğu inancından hareketle zamanlarının imkan, şart ve usulleri çerçevesinde bulundukları her yerleşim merkezinde ve gittikleri her yerde belirtilen türden sayısı su tesisleri kurmuşlardır. Varlıklı olanlar müstakil su tesisi kurarken, orta halli olanlar da çevrelerinde yapılan herhangi bir su tesisine imkanları ölçüsünde katkıda bulunmuşlardır. Köyde, kentte, bağda, bahçede, yol kavşağında ve benzeri yerlerde yapılan çeşme ve pınarlarla kazılan kuyular uzun yıllar çevre sakinleriyle yolculara tatl ve leziz sular sunarak ab-ı hayat menbaı olmuşlardır. Yaşayan eserler ve eldeki belgeler bu gerçeği dile getirmektedir." (Ateş, 1987, s. 2-3).

13 Konu hakkında bkz. (Durmuş, 2009, s. 398-401). 
vurgulanarak tüm dünyanın hükümdarlığına sahiplik ima edilir ve Sultan Süleyman böyle bir güce sahip olmasıyla övülür. ${ }^{14}$

“mücri'l-miyâhi'l-kesîreti fî̀ bilâdi'l-Müslimîn siyyemâ kudse'l-mübâreke ve Kostantıniyyete'l-mahmiyyete” (Ateş, 1987, s. 11)

“[...], Müslümanların beldelerinde, özellikle mübarek Kudüs ve korunmuş Kostantıniyye'de çok sular akıtan, [Kanunî Sultan Süleyman]” (Ateş, 1987, s. 24)

Bir yere su götürmek (çeşme, sebil, köprü, şadırvan, su yolu, su ark1 vb. yaptırmak), başlı başına sevap kazanma vesilesi olarak halk anlayışında mevcutken bilhassa kutsal topraklara su taşımak, oranın neşvünema bulmasını sağlamak ayrıca önemsenir. Sultan Süleyman Müslümanların yaşadığı beldelere çok sular akıtması yönüyle övülürken bu anlayışın izi görülür ve suya hükmetmek hükümranlık kabiliyetinin göstergesi olur.

“afâda şe’âbîbe'r-rahmeti alâ âbâihi'l-izâm” (Ateş, 1987, s. 12)

“Allah [...] [Kanunî Sultan Süleyman'ın] Büyük babaları ve değerli geçmişleri üzerine rahmet yağmurlarını bolca yağdırsın” (Ateş, 1987, s. 25)

İyi dilek temennisi ve dua maksadıyla söylenen sözlerde, rahmet yağmurunun (teşbih-i beliğ yapılmıştır) Sultan Süleyman'ın ataları üzerine yağması istenirken hayırlı bir evlat yetiştiren atanın Allah'ın rahmetine nail olacağı anlayışına rastlanır. İkinci olarak değinilmesi gereken husus; "rahmet ile yağmur" arasındaki bağdır. Rahmet; esirgeme, şefkat gösterme, severek ve acıyarak koruma manalarına gelir ve “rahim”le (uterus) kökteştir. Kur'ân' da Allah'a nispet edilerek kullanımı yaygındır. ${ }^{15}$ Yağmur yağdırmak için Allah'ın şefkatine daha çok nail olacağına inanılan ve acizliği temsilen çocukları çayıra çıkarıp dua ettirmek, rahmet kelimesin anlamıyla ilişkilidir. ${ }^{16}$ Başka bir deyişle yağmur ve rahmet; üst/yukarı konumdan alt/aşağ konuma doğru bir geçişi anlatmakta, acziyet ve muhtaçlığı gidermesiyle ele alınmaktadır. Ayrıca insanın muhtaç olduğu rahmetin mecaz yoluyla yağmura ad olması da benzer bir anlam patikasından geçerek ortaya çıkmış olmalıdır. "Yağmur yağıyor" demek yerine "rahmet yağıyor" şeklindeki kullanımın tercih sıklığı, bu anlayışın toplum hafızasına ve dile sağlam bir şekilde yerleştiğini göstermektedir. ${ }^{17}$

14 Beyhan Kanter'e göre toprak, bireyin yaşamaya mahkûm olduğu sınırlandırılmış bir mekândır. Çünkü darlığı, kuşatılmışlı̆̆ temsil eder. Su ise aksine özgürlüğü, uçsuz bucaksızlığı sembolize etmektedir. Bkz. (Kanter, 2006, s. 32). Bu manada düşünülecek olursa padişahların toprak hâkimiyetinin yanı sıra su hükümranlığının vurgulanması "kazanılmış zaferin sınırlarını ve sınırsızlığını" ima eder.

15 Ayrıca; “Kur'an'da rahmet Tevrat'a, Kur'an'a, Hz. Peygamber'e ve insanlara da nisbet edilmiştir" (Birışık, 2007, s. 419).

16 Çocuklara yağmur duası ettirme geleneği için bkz. (Kobya, 2014, s. 204-353); (Schimmel, 2004, s. 29); (Demren, 2016/12, s. 76-92).

17 Benzer bir kullanıma "bereket yağıyor" ifadesinde rastlanır. İnsanın yiyeceği gıda, yağmurdan sonra oluşan bereketlenme sonucu husule gelir. Dolayısıyla halk dilinde yağmur, kendi sonucu olan “bereket” sözcügüyle eş anlam kazanır. Bereket, mecaz yoluyla yağmura ad olur. 
Müslümanlar arasında yaygın bir gelenek olarak kabir sulama davranışı vardır. ${ }^{18}$ Üstteki alıntıda, vefat etmiş ataların ruhunun rahmet yağmuruna nail olması dileğinin arka planında, kabir sulama âdetinin izi sürülebilir.

“ravza-i ilm u ulemâ ve devha-i fazl u fuzalâ mâ-i nemâ-yı terbiyetleriyle ma'mûr ve ezhâr-1 lutf u himâyetleriyle magmûr [...] olup" (Ateş, 1987, s. 12-3)

“[...] ilimler ve âlimler bahçesi ile fazilet ve faziletliler ağacının eğitip geliştirme suları ile şenlendirilip lütuf ve koruma çiçeklerine gömülmesine [...]” (Ateş, 1987, s. 26)

“Bahçede akan su teması”ndan yola çıkılan anlatımda, Kanunî Sultan Süleyman'ın saltanat günlerinde ilmin ve âlimlerin 'lütuf ve koruma çiçekleriyle bezeli bir bahçeye' döndüğü belirtilmiştir. Bu bahçede fazilet ile faziletliler ağacından bol bol yetişmiştir. Bahçeyi sulayıp filizlendiren su ise terbiyedir. Terbiyenin suya benzetilmesinde onun "nema"19 yani geliştirme, büyütme, arttırma, çoğaltma özelliği etkili olmuştur. Terbiye suyu ile gelişen fazilet ağaçları ilimler-âlimler bahçesini oluşturmaktadır.

“ayn-1 inâyetleriyle memâlik ve emsâr mesâcid-i bî-şümâr ve savâmi'-i bedî’u'l-etvâr
ve cevâmi'i-i kesîrü'l-envâr ile şeref ve ibtihâc ve revnâk ve revâc bulup safahât-1
rûzgârda zuhûr bulan âsâr hayr-i halef mesâbesinde fi'l-aktâri ve'l-emtâr bâ'is-i
zikr-i cemîl ve sebeb-i ecr-i cezîl olmışdur.” (Ateş, 1987, s. 13)
"Böylece [Sultan Süleyman'ın] inayet gözleri ile memleketler ve büyük şehirler,
sayısız mescitler, benzeri olmayan mabedler ve çok türlü câmiler ile şeref, sevinç,
parlaklık ve revaç bulup, zaman safhalarında meydana gelen eserler, ülkeler ve
şehirlerde halefin hayırlısı olarak [köşe bucak yağan yağmur derecesince] güzel bir
şekilde anılmasına vesile ve bol mükafat almasına sebep olmuştur.” (Ateş, 1987, s. 26)

Sultan Süleyman'ın gayretiyle türlü yapıların imar edildiği, bunların da padişahın anılmasına aracı ve bol mükâfat almasına sebep olacağı söylenmiştir. İşte bu anma ve mükâfatlar sayılamayacak kadar çok olmak bakımından köşe bucak yağan yağmurla birimlendirilmiştir. Dolayısıyla da yağmurun “sayılamazlık, bolluk” sembolü olduğu anlaşılmaktadır.

“ecra'llâhu sicâle ihsânihi alâ sükkâni'r-rub’i-1-meskûn mâ cereti'l-enhâru ve'luyûn” (Ateş, 1987, s. 13)

“Allah onun [Kanunî Sultan Süleyman] iyilik yağmurlarını, iskan olunan dörtte birin $^{20}$ sakinleri üzerine, ırmaklar ve pınarlar aktığı müddetçe akıtsın [...]” (Ateş, 1987, s. 26)

18 Benzer bir uygulamanın Sümerlerde yaşatıldığı vakidir. Gılgameş Destanı'nda Enkidu hastalanıp ölüm döşeğine düşünce hayıflanır ve ölünce üzerine/mezarına soğuk su döküleceğini söyler. Bkz. (Sezen, 2016, s. 152).

19 "[...] hıtâm-1 mâ‘diletleri ravza-i ilm u ulemâ ve devha-i fazl-1 fuzalâ mâ-i nemâ-yı terbiyetleriyle ma'mûr [...] olmışdur.” Bkz. (Ateş, 1987, s. 12-3)

20 “Asıl metinde geçen 'alâ sükk'ani'r-rubi'l-meskûn' cümlesinin anlamı 'oturulan dörtte birin oturanları üzerine' olup, bununla dünyanın kara olan 1/4 kısmı kasdedilmiş olduğu kanaatindeyiz.” Bkz. (Ateş, 1987, s. 26). 
Padişah tarafından yapılan iyilikler yağmura benzetilmiş ve bu iyilik yağmurunun yeryüzü̈ ${ }^{21}$ sakinleri üzerine "pınarlar ve ırmaklar aktığı" müddetçe yağması temennisinde bulunulmuştur. Buradan hareketle akarsuyun akış süresinin iyi dilek temennilerinde kullanıldığg 1 ve bunun uzun bir zamanı kapsadığı sonucu çıkarılabilir. Neticede ise akarsuyun bir uzunluk birimi olarak algılandığı ve zamana içkin yönüyle uzun zamanı temsil ettiği söylenebilir.

“pâdişâh-1 âlî-şân [...] hazretlerinün himmet-i vâlâ-nehmetleri teksîr-i ma’âlim-i hayrâta maksûr ve niyyet-i şâfî-reviyyetleri tevfîr-i merâsim-i meberrâta mahsur olmagın hâtır-1 âtır-1 deryâ-makâtır ilhâm-1 mezâhirlerinde bu fikr-i bikr-i latîf âbdâr cârî ve ber-karâr oldı" (Ateş, 1987, s. 13)

“[...] şanı yüce padişah [...] hazretlerinin yüce himmet ve gayretleri, hayır eserlerini çoğaltmaya yönelmiş, her yönden düşünüp taşınma sonucu olup, şifa niteliğindeki yeterli niyetleri, iyilik işlerini arttırmaya hasredilmiş olduğundan bu güzel parlak ve taze düşünce, ilham yeri olan deniz damlaları gibi çok ve güzel kokulu gönüllerinde devamlı bir şekilde geçerek karar kılmıştır.” (Ateş, 1987, s. 26-7)

Su yapıları, bir kimsenin hayır maksatlı yaptırdı̆̆ı temel inşalar arasındadır. Son derece kutsal kabul edilen bu gibi uğraşılar sayesinde hem yaşanılan zamana hem de geleceğe yarar sağlanmış olunur. Hayrat yaptırmak, kişinin pek çok hayır dua almasına vesile kabul edilir.Yukarıdaki metne göre Sultan Süleyman da, şanlı ve yüce karakterini yansıtan nice su hayratı yaptırmıştır. Hayır eserlerini çoğaltmak, sultanın halkına gösterdiği himmetlerdendir. Üzerinde inceden inceye düşünülüp taşınılan her bir eser halka şifa dağıtmaktadır. Yapılan inşalar, iyiliklerine iyilik katan padişahın güzel düşüncelerinden ileri gelmektedir. Padişahın bu düşüncelerinin kaynağı ise denize benzetilmiştir. Hal böyleyken Sultan Süleyman'ın düşüncelerinden dökülen tüm projeler de bu ilham denizinin damlası olmaktadır. İlham denizinden dökülen her proje damlacığı padişahın güzel kokulu yüreğinden durmadan geçmekte ve böylece husule gelmektedir. ${ }^{22}$

“dâru'l-karâr-1 selâtîn-i kâm-kâr eskenehumu'llâhu fî̀ cennetin tecrî min tahtihe'lenhâr olan mahmiye-i mahmude-i mezbûre ve mahrûsa-i mes'ûde-i mezkûrede vâki’ olan mesâcid ve savâmi' ve amâyir [...] ve hammâmât ve hânât [...] riyâz ve hadâ'ik ve hıyâz miyâh-1 selsebîl ile mahsûd-1 huld-berîn ve şerâb-1 tahûr ile magbût-1 nigâristân-1 Çîn olup" (Ateş, 1987, s. 13)

21 Bachelard, toprak (yeryüzü) ile suyun alakasını şöyle dile getirir: Su "toprağın kanıtıdır zaten. Toprağın yaşamıdır. Bütün manzarayı kendi yazgısına doğru sürükleyecek olan sudur.” (Bachelard, 2006, s. 74). Toprağın toprak olma özelliğini ortaya çıkaran su (yağmur), istikrar kabiliyeti derecesince iyiliğe dönüşüp yeryüzüne akar ve toprağın yazgısını (iyi yönde) değiştirir.

22 Anlatımın bu kısmında, klasik Türk şiirine göre evrenin yaratılışına atıf yapıldığı düşünülebilir. Kısaca dile getirmek gerekirse; Allah evreni yaratacağı vakit yeşil/ yeşim bir taşa (tasavvufta nûr-1 Muhammedî, cevh-i mahfuz, akl-1 küll, izâfî ruh olarak bilinir) aşk ile bakmış ve bu taş utanç ile eriyip suya dönmüştür. Sudan çıkan köpük damlalarından evrenin öğeleri yaratılmıştır (Bkz. (Levend, 1984, s. 14-20); (Sezen, 2020, s. 330). Yukarıdaki anlatımla bu yaratılış bahsi birlikte değerlendirilecek olursa Sultan Süleyman'a Allah'tan ilham (denizin temsili) gelmekte ve bu ilham denizinden kabaran köpüklerden proje damlacıkları hâsıl olmaktadır. 
“[...] isteğine ulaşan mutlu sultanların -Allah onları altından ırmaklar akan cennette iskan etsin- kaldığı yer olup, himaye edilen, övülen ve korunan söz konusu yerde (İstanbul'da) bulunan, mescidler, mabedler, imaretler, [...] hamamlar, hanlar [...] ve ağaçlı, suyu çok olan hadika türünden bahçeler, havuzlar, tatlı sebil suları ile cenneti kıskandıracak ve temiz içecekleri ile resim, nakış ve benzeri güzellikleriyle ünlü Çin'i gıbta ettirecek nitelikte olmuştur.” (Ateş, 1987, s. 27)

Kur'ân ayetlerinde sık sık geçen "altından ırmaklar akan cennet" ifadesi, su ile cennet kelimelerinin birbiriyle uyumunu göstermektedir. Sultan Süleyman'a layık görülen cennet makamının da tıpkı böyle niteliklere sahip olduğu vurgulanmıştır. İnşa ettirdiği hamamlarla, havuzlarla, suyu bol ve birbirinden güzel bahçelerle, tatlı sebil suları ve benzeri yapılarla Sultan'ın cenneti hak ettiğine delil getirilmiştir. Kutsal (övülmüş, korunan) kabul edilen şehirlerden biri olan İstanbul'un bu yapılar sayesinde güzelliğine güzellik katılmış, dolayısıyla da şehir eşi bulunmaz bir değer kazanmıştır. Sonuç olarak su yapılarının (suyun) şehirleri medeniyet seviyesine yükseltme işlevine dizelerde yer verildiği söylenebilir.

"reşehât-1 in’âmları nisân-sân efrâd-1 insâna şâmil ve kâfi ve sicâl-i birr-i âmları ehl-i imâna kâfil ve şâfî ola” (Ateş, 1987, s. 13)

“Onun nimet damlaları, nisan [yağmuru] gibi insanların hepsine şamil ve yeterli olacak bollukta, genel iyilik yağmurları iman ehline tekeffül edecek kifâyet ve yeterlilikte olsun." (Ateş, 1987, s. 27)

Yağmurun; nimet, rızık, bolluk, çokluk, bereket ve iyilik kavramlarıyla eşgüdüm halinde kullanılması oldukça yaygındır. ${ }^{23}$ Nitekim yukarıdaki ifadeye göre Sultan Süleyman'ın dağıttığı nimetlerin yağmur kadar sayısız ve bereketli olduğu, herkese yettiği söylenir. Yaptığı iyiliklerse yağmur misali sayılamayacak kadar çoktur (yağmur çokluk sembolüdür). Bu iyilik yağmurlarının mümin kimselere yetişir kifayette olduğu belirtilmiştir.

“havâss-1 Kostantıniyye hamâha'llâhu ani'l-beliyyeden Kağıdhâne suyı dimek ile ma'rûf cârî ve tâhir ve sâfî ve nazîri nâdir azbun furâtun sıfat-1 zatı henîen merîen âsâr-1 sıfâtı olan mâ'i icrâ içün mevâzı'-1 ba'îde ve mevâkı'-1 adîde [...] ve cibâl-i refî'ada tâkât-1 âliye-i metîne ve cüsûr-1 galiye-i raşine ve tarâık-1 mu'ayyene ve merâfik-1 mübeyyene bünyâd itmişlerdür ki evdâ-i garibe-i ünsi şi’âr-1 cinnî-girdâr ve etvâr-1 acîbe-i Süleymân-âsârını mu'âyene ve müşâhede eden ahyâr ve ebrâr bânî-i mebânî Süleymân-1 sânî Hazretlerine bî-ihtiyâr du'âhâ-yı besyâr iderler." (Ateş, 1987, s. 13-4)

“[...] İstanbul'un -Allah onu belâdan korusun- seçkin yerlerinden olan Kağıdhane Suyu diye bilinen akar, temiz, saf, benzeri az, zâtî özelliği tatlı su ve özelliklerinin

23 Yağmur, Kur'ân ayetlerinde de nimet veya rızık olarak anılır. Örneğin Fatır 35:3'te şöyle geçer: "Ey insanlar! Allah'ın size olan nimetini hatırlayın. Allah’tan başka size göklerden ve yerden rızık veren bir yaratıcı var mı? O’ndan başka hiçbir ilah yoktur. O halde nasıl oluyor da haktan döndürülüyorsunuz?’ Ayrıca bkz. (Baktır, 2001, s. 382) 
eserleri -afiyet, şifa olsun; boğazında kalmasın- olan suyu akıtmak için uzak yerler, sayısız mevkiler [...] ve yüksek dağlarda yüce ve sağlam kemerler, değerli ve muhkem köprüler, muayyen yollar ve belirli su ayakları yapmışlardır ki, insanlar tarafından yapılmış olmakla beraber bu eserlerin alışılmamış özellik ve güzellikteki garip halleri, cinlerin Hz. Süleyman için yaptıkları eserlerin acaib şekillerine benzemektedir." (Ateş, 1987, s. 27)

Akması, temizliği, saflığı, eşi benzerinin az bulunması, tatlılığı, afiyet ve şifa bahşetmesi, boğazdan kolayca kayıp geçmesi Kâğıthane suyunun övülen özellikleridir. Bahsi geçen güzel suyun İstanbul'a getirilmesi amacıyla inşa edilen kemerler, köprüler, su ayakları vb. yapılar güzellikleri ile adeta cinler tarafından yapılmış izlenimi vermektedir. Sultan Süleyman da cinlere hükmederek kendisine türlü yapılar inşa ettiren Hz. Süleyman'a benzetilmektedir. Bir başka değişle su kemerlerinin bakan kişiyi daima büyüleyen görüntüsü, suyun kilometrelerce öteden taşınıyor olması gerçeği gibi etkenler vakfiyenin müellifinin dikkatini çekmiş ve Hz. Süleyman'ın cinlerle olan ilişkisine dair anlatılara gönderme yapmasını sağlamıştır.

“uyûn-1 atîka ve cedide âb-1 revân ile mâ-lâ-mâl ve cevâmi’ ve savâmi'-i cennetmisâl oldukda belde-i tayyibe-i ma'mûrede olan her şey 've mine'l-mâ'i külle şey’in hayyin' muktezâsınca hayât-ı nev bulup mukim ü müsâfir ve bâdî ve hâdırdan teşnegân furâta ve küştegân menba'-1 hayâta irdüklerinde;

Beyt: Âb-1 hayvânî ki İskender be-tarîkî neyâft

Der-uyûn-i pâdişâh-1 heft kişver yâftem

diyü bu beyti vird-i subh û nehâr [..] tekrâr [...] ideler.” (Ateş, 1987, s. 14)

“[...] eski ve yeni pınarlar akarsu ile dopdolu olmuştur. Böylece Câmiler ve mabedler cennet gibi olup, güzel ve bakımlı beldede (İstanbul'da) olan her şey -Her canlı şeyi sudan yarattık- buyruğu uyarınca taze hayat bulup şehirde oturan, yolcu ve dışarıdan gelenlerden susayanlar tatlı suya ve öldürülmüşler hayat kaynağına erdiklerinde; Beyt: 'İskender'in karanlıkta bulamadığı hayat suyu ki, ben onu yedi iklim padişahının çeşmelerinde buldum' diye bu beyti sabah-akşam sürekli şekilde söyler dururlar.” (Ateş, 1987, s. 28)

Vakıf aracılığıyla yenilenen su yapıları, eski yeni demeden bütün pınarların suyla dolmasını sağlamıştır. Böylece suya kavuşan camilerden mabetlere kadar her yapı cennete dönmüştür. Cennet ile su unsurlarının birlikte anılması oldukça yaygındır. Zira ulaşılabilecek en güzel yer (ütopya, cennet vs.) tasvirinde suyun varlığı hemen hemen vazgeçilmezdir.

Dizelerde Enbiya suresinin 30. ayetinden alıntı yapılarak suyun yaratılıştaki önemi vurgulanmış, taze hayat bahşetmesi özelliğine değinilmiştir. Vakıf sayesinde şehir (İstanbul) halkına, yolculara ve susuz kalmış herkese âbıhayât özellikli tatlı sudan sunulduğu belirtilmiştir. İnsanlarsa gece gündüz demeden suyun banisine şükür duası etmektedir. Çünkü İskender'in 
zulümatta (karanlık) bulamadığı âbıhayâtı, Sultan Süleyman'ın yaptırdığı çeşmelerden ${ }^{24}$ içmenin nasip olduğu ifade edilmiştir.

“ne’ûzu Bi’llâhi Te’âlâ inhidâmi külli vâki’ olup mahsul-i evkâf-1 mezkûre vefâ itmezse mahmiye-i Kostantınıye'de binâ buyurdıkları câmi'-i şerîf ve medâris-i aliyye ve ma'bed-i münîf ve imâret-i celiyyeleri evkâfınun zevâ'idinden tecdîd ve termîm ve tekmîl ve tetmîn olunup dâ'imâ mâ-i sâfî bi-feyzi'llâhi âmme-i enâma kâfi ve şâfî ola." (Ateş, 1987, s. 16-7)

“Allah korusun, tamamen yıkılıp sözü geçen vakıfların geliri onarımlarına yeterli olmazsa mahmiye-i İstanbul'da yaptıkları câmi-i şerif, yüce medreseler, kutsal mabed ve belirgin imaretlerine ait vakıflarının gelir fazlasından yenilenip, onarılıp kemale erdirilerek tamamlanıp, devamlı saf su Allah'ın bol lütfu ile bütün insanlara yeterli ve şifa verici nitelikte olsun.” (Ateş, 1987, s. 31)

Su yapılarının onarım ve bakım masrafları için vakfın geliri yetişmezse İstanbul'daki diğer vakıfların gelirinden buraya kaynak aktarılması hususundan bahsedilen dizelerde suya dair temenniler dikkat çeker. Zira su hep aksın, Allah'ın lütfuyla herkese yetip şifa versin, denilmektedir. Buradan hareketle makbul bir suyun özelliklerinin neler olması gerektiği anlaşılır. Ayrıca değinmekte yarar var ki halk arasında suyun türlü dertlere şifa olduğu inancıyla "şifa tası" denen bir kültür doğmuştur. Suyun bu şifa özelliğine getirilen kanaat hayli ileri düzeydedir. ${ }^{25}$

“Sarafa'llâhu [...] edâme umre bânihâ mâ cera'l-uyûn ve'n-nehr.” (Ateş, 1987, s. 17)

“Allah [...] Nehir ve pınarların aktığı sürece bânilerinin ömrünü devam ettirsin.” (Ateş, 1987, s. 31)

Sümerler zamanında bile örneğine rastlanan bir gelenek "su üzerinden iyi dilekte/duada bulunma” âdetidir. ${ }^{26}$ Tıpkı bu âdet gibi hayır inşası yaptıran birinin (Kanunî Sultan Süleyman) uzun ömür sürmesi dileği, nehir ve pınarların yıllar boyu akması üzerinden dile getirilmiş ve suyun uzun zamana içkin yönü üzerinde durulmuştur.

24 Tarihi süreçte çeşmeler, suyun yerleşim merkezlerine getirilmesiyle önem kazanmıştır. "Suyun kentin içine sokulmasıyla birlikte, su dağıtımının kamusal bir mesele olarak algılanması, Mezopotamya ve Doğu Akdeniz'e özgü bir geleneğin oluşmasını sağlamıştır. Çeşmelerin en basit biçimlerinin Mısır ve Sümer şehirlerinde ortaya çıktığı tahmin edilmektedir”. Orta Çağ Avrupa'sında (Hristiyanlar arasında) çeşmeler 'saflık, bilgelik, masumiyet ve cennet bahçesi' ile ilişkilendirilmiştir. İslamiyet'te ise cennetteki Tûbâ ağacının dibinden kaynadığına inanılan âbıhayâtın dünyadaki yansıması olarak görülmüştür ve daima kutsal kabul edilmiştir. (Demirağ, Güz 2017/2, s. 1046). Cennetteki Tûbâ'nın altından kaynayan âbıhayât eski Türk mitolojisinde hayat ağacının dibinden çıkmaktadır. Konu hakkında; Ögel, 2014/2, s. 554, 613-4; Ögel, 2014/1, s. 109-20'deki Er-Sogotoh efsanesine bakılabilir.

25 Şifa tasları, üzerinde şifa verdiğine inanılan çeşitli ayetler veya sözler yazan yahut türlü işlemelerle süslenmiş taslardır. Bu tip taslara doldurulmuş nisan yağmurundan, taze pınar suyundan veya zemzem suyundan içen kişinin (hayvanın) şifa bulup hastalıktan kurtulacağına inanılır. Tarladaki mahsulün üstüne yine bu tasla su saçılması gelenektir. Konu hakkında bkz. (Aksoy, 1974, s. 35); (Gedük, Güz 2017/2, s. 358-61).

26 Suyun iyi dilek-temenni özelliği Gılgameş Destanı'nda da geçer: "Edebi metinlerde yağmur bir benzetmede kullanılacağı zaman, adeta klâsikleşen bir yönelimle, "bereket"e karşlık gelir. Nitekim Enkidu iyi dilek temennisi olarak bereketli yağmurların arkadaşının tarlasına yağmasını dileyerek bu bereket imini tekrarlar.” (Sezen, 2016, s. 149). 


\begin{abstract}
“imâmeyn-i hümâmeyn ve âlimeyn-i kamkâmeyn şemseyn-i neyyîreyn ve bedreyn-i münîreyn bahr-i rabbânî Ebû Yûsuf imâm-1 sânî ve hibr-i ma’ânî İmam Muhammed Şeybânî katlarında [...]”' (Ateş, 1987, s. 18)

“[...] iki büyük hizmetli imam, ulu bilgin, aydınlatıcı iki ay ve iki güneş olan İlahî deniz, ikinci imam Ebu Yusuf ile manaları müdrik olan İmam Muhammed Şeybânî katlarında, [...]" (Ateş, 1987, s. 32)
\end{abstract}

Dizelerde övülen iki kişinin nitelikleri sıralanırken onlara "ilahi deniz" denilmiş ve ilâhî yani ledünnî ilim denize benzetilerek bahsi geçen kişilerin mizaçları ile bağdaştırılmıştır. İlmin deniz motifiyle kurgulanmasının yanı sıra kültürel bir kullanım olarak "su öğeleri ve 1şık/ Güneş" birlikte anılmıştır. Zira her ikisi de yaşamın kaynağı kabul edilir ${ }^{27}$ ve doğumu simgeler. ${ }^{28}$

\title{
SONUÇ
}

Sonuç olarak İslamî öğelere sıklıkla yer verildiği görülen vakfiyeden hareketle; makbul bir suyun ne gibi özellikler taşıması gerektiği (daima akan, herkese yeten, temiz ve saf, eşi benzeri az bulunan, tatlı, afiyet ve şifa bahşeden, boğazdan kolayca kayıp geçen) veya suyun şifa verdiğine inanılması gibi pek çok bilgiye ulaşmanın mümkün olduğu söylenebilir. Örneğin su; hamd ü senanın sınırsızlığını anlatmak için bir aracı, Allah'ın hikmetine ve yaratma gücüne bir delil, padişahın taşıması gereken adalet ve doğruluk yetisinin sınırsızlığı hakkında misal, padişahların başarı-hayır-iyilik ve sevaplarını arttırmaya vesile, ledünnî/ilmî/kat‘î gerçeklere ve şeriata temsil, hükümranlığgn genişliğine semboldür. Rahmet temsili olup dillerde iyi dilek temennilerine, dualara dönüşür. Terbiyeye benzetilerek suyun geliştirip büyüttüğü, arttırıp çoğalttığı vurgulanır. Padişahın hayırla anılma sıklığını anlatmaya yarar. Yapılan iyiliğin çokluğunu anlatır. Uzun soluklu zamana ve sürekliliğe temsil olup iyi dilek temennilerinde kullanılır. Padişahın halkına bahşettiği himmetin göstergesidir. Güzel ve yararlı projeler üreten düşüncelerin çıktığı ve ilhamın geldiği yere temsildir. İnşa edilen projelerin çokluğunu anlatır. Şehirleri medeniyet seviyesine yükseltir ve eşi benzeri olmayan güzelliklere kavuşturur. Cennet tasvirlerinin vazgeçilmez unsurudur. Kişiyi cennete ulaştırmaya vesile olur. Bulunduğu yeri cennete çevirir. Nimet temsilidir, nimetin bolluğunu ve getirdiği bereketi anlatır. Bakanı büyüleyen sahneler oluşturur. Yaratılışın temelidir. Tazeler, hayat bahşeder. Şükür duası edilmesine vesiledir. Ledünnî/ilahî ilmi sembolize edip övülen kişilerin mizacına benzetme olur.

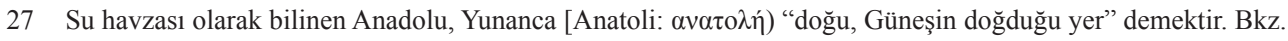
(Karakurt, 2011, s. 145).

28 Hristiyanlıkta Hz. İsa Güneşle sembolize edilirken vaftiz suyu yeniden doğumun karşılığıdır. Işık ve su birlikteliğinin Hristiyanlık üzerinden ele alınması hakkında bkz. (Sezen, 2020, s. 55-63). 
Hakem Değerlendirmesi: Dış bağımsız.

Çıkar Çatışması: Yazar çıkar çatışması bildirmemiştir.

Finansal Destek: Bu çalışma İstanbul Üniversitesi Bilimsel Araştırma Projeleri Koordinasyon Birimi tarafından desteklenmiştir. Proje numarası: 50103’tür. Makale adı geçen doktora tez projesindeki ilgili bölümden geliştirilerek üretilmiştir..

Peer-review: Externally peer-reviewed.

Conflict of Interest: The author has no conflict of interest to declare.

Grant Support: This study was supported by the Scientific Research Projects Coordination Unit of Istanbul University. Project number: 50103. The article has been developed and produced from the relevant section in the aforementioned doctoral thesis project..

\section{KAYNAKÇA/REFERENCES}

Acar, K. (2013). Su medeniyeti sempozyumu. Konya: Konya Büyükşehir Belediyesi (KOSKİ) Yayınları. Aksoy, O. (1974). Şifa tasları. Türk Etnografya Dergisi (14), 35.

Ateş, İ. (1987). Kanuni Sultan Süleyman'ın su vakfiyesi. Ankara: Kültür ve Turizm Bakanlığı Yayınları.

Bachelard, G. (2006). Su ve düşler. (O. Kunal, Çev.) İstanbul: YKY.

Baktır, M. (2001). İstiska. DİA, 23, 382. İstanbul: TDV Yayınları.

Batuk, C. (2006/2). Âdem ve Havva'nın kitabı: Eski ahit apokrifasında Âdem ve Havva'nın hayatı. Hitit Üniversitesi İlahiyat Fakültesi Dergisi, 5(10), 51-96.

Birışık, A. (2007). Rahmet. DIA, 34, 419. İstanbul: TDV Yayınları.

Cebecioğlu, E. (ty.). Tasavvuf terimleri ve deyimleri sözlüğü. e-kitap. 07 15, 2020 tarihinde http:// tasavvufkitapligi.com/i/uploads/429779tasavvufterimleri-ve-deyimleri-sozlugu.pdf adresinden alındı

Demirağ, D. (Güz 2017/2). Su medeniyeti. Z Dergisi, 100-7.

Demren, Ö. (2016/12). Yağmur yağdırma ritüeli çerçevesinde ortaköy yağmur duası. Türkbilig, 76-92.

Durmuş, İ. (2009). Sözlük. DİA, 37, 398-401. İstanbul: TDV Yayınları.

Gedük, S. (Güz 2017/2). Suyun iyileştirici gücü: Şifâ kapları. Z Dergisi, 358-61.

Genesis/Yaratılış. (tarih yok). 07 26, 2020 tarihinde https://kutsalkitap.info/tr-gen1.html adresinden alındı Kanter, B. (2006, Kasım). Toprak ayna su ve imgeden aşka giden yol. Türk Edebiyatı Dergisi (397), 32.

Karakurt, D. (2011). Türk söylence sözlüğ̈̈: Açıklamalı ansiklopedik mitoloji sözlüğ̈̈. 07 01, 2020 tarihinde https://upload.wikimedia.org/wikipedia/commons/3/34/Turk_Soylence_Sozlugu.pdf adresinden alındı

Kobya, E. Ş. (2014). Türkiye'de yağmur törenleri ve yağmurla ilgili inanışlar. Doktora Tezi, Atatürk Üniversitesi, Erzurum.

Kolektif. (5-8 Mayıs 2000). Osmanlı su medeniyeti (Uluslararası Sempozyum). İstanbul: İSKİ Yayınları.

Kubbealtı Lugati. (tarih yok). 07 23, 2020 tarihinde http://lugatim.com/s/m\%C3\%BCtevelli adresinden alınd1

Kubbealtı Lugati. (tarih yok). 07 21, 2020 tarihinde http://lugatim.com/s/vakfiye adresinden alındı

Kur’ân-1 Kerîm. (tarih yok). 07 19, 2020 tarihinde http://kuran.diyanet.gov.tr/mushaf adresinden alındı

Kuruçay, A. (2017/2). Su ve şifa. Z Dergisi.

Levend, Â. S. (1984). Divan edebiyatı: Kelimeler ve remizler, mazmunlar ve mefhumlar (4. b.). İstanbul: Enderun Kitabevi. 
Ögel, B. (2014). Türk mitolojisi (Cilt 1-2). Ankara: TTK Yayınları.

Öztürk, S. (2017/2). Osmanlı şehirlerinin vakıf suları. Z Dergisi, 126-33.

Sarıdikmen, G. (2017/2). Mîmârî, süsleme ve kitâbelerine göre istanbul çeşmelerinin dönemsel özellikleri. Z Dergisi, 200-11.

Schimmel, A. (2004). Tanrı'nın yeryüzündeki işaretleri: İslam'a görüngübilimsel yaklaşım. (E. Demirli, Çev.) İstanbul: Kabalcı Yayınları.

Sezen, G. (2016). Gılgameş Destanı'nda suyun izdüşümü. International Journal of Languages 'Education and Teaching (IJLET), 4(2), 143-57.

Sezen, G. (2020). Klasik Türk şiirinde su. Doktora Tezi, İstanbul Üniversitesi, İstanbul.

Werner, (. A. (2011). Padişahın huzurunda (Elçilik Günlüğü, 1616-1618). (T. Noyan, Çev.) İstanbul: Kitap Yayınevi.

Yaratılış. (tarih yok). 07 26, 2020 tarihinde https://incil.info/ adresinden alındı 